\title{
PENSAMIENTO COMPLEJO
}

$<<$ Complexus: lo que está tejido en conjunto >>

La concepción del conocimiento científico lleva mucho tiempo y su estructuración es continua, tiene como misión disipar la aparente complejidad de los fenómenos naturales, para revelar de forma simple, no simplificadora, a qué obedecen y cómo se estructuran, por eso la complejidad debe abordarse como un problema y no como una solución. Es evidente que la complejidad hace presencia cuando reina el pensamiento simplificador, la simplificación no es un camino adecuado para entender, dilucidar y manejar la investigación científica, es por lo general reduccionista y ligera en sus interpretaciones.

La complejidad de pensamiento debe ser entendida como una red de constituyentes heterogéneos unidos de forma inseparable, asocian la paradoja de lo simple y lo complejo, uno y múltiple, es una secuencia interrelacionada de eventos, acciones, interacciones, retroacciones, determinaciones y azares, que son componentes del mundo fenoménico o natural, como bien lo señalaba MORIN entre 1976 y 1988.

Al respecto MORIN, afirmaba: <<Nunca pude, a lo largo de mi vida, resignarme al saber parcelarizado, nunca pude aislar un objeto de estudio de su contexto, de sus antecedentes, de su devenir. He aspirado siempre a un pensamiento multidimensional. Nunca he podido eliminar la contradicción interior. Siempre he sentido que las verdades profundas, antagonistas las unas de las otras, eran para mi complementarias, sin dejar de ser antagonistas. Nunca he querido reducir a la fuerza la incertidumbre >>.

Es aquí y en este sentido, en donde cobra fuerza la Universidad como alma mater, como intricada red formadora de pensamiento, se muestra en todo su esplendor cuando puede moverse constructivamente entre las diferentes posiciones de pensamientos, dándole valor científico a su productividad compleja, de la cual nacen novedosas formas de interpretación que permiten el desarrollo social a la par del crecimiento universal del conocimiento. Sí primaran las formas simplistas de interpretación y desapareciera la controversia, sí se enfocara solo la unidad dejando del lado el conjunto y sus relaciones, no podría existir la Universidad, no tendría sentido la academia y su valor sería tan absurdo como sus mismas creaciones.

Modernamente estamos abocados, como en el pasado lo estuvimos, a mantener una Universidad plural, una investigación multidireccional, un diálogo polifacético y creativo, es la única forma viable de erigir un camino limpio hacia la paz, la democracia y la verdadera formación de relevos fértiles, más aún, en un medio como el nuestro, que dejando de lado el pensamiento complejo, tiende a privilegiar ciertas actitudes reconocidas por sus carencia, que prime: complejos antes que simplificares, antagonistas antes que reduccionistas. 
Como nota final nuestra Revista envía un cordial agradecimiento a todos los investigadores que con sus publicaciones nos apoyan, a aquellos que con sus labores de revisión crítica y aporte de conocimientos nos permiten guiarnos sin perder la senda de la investigación compleja, y en general a todos los intelectuales y académicos valiosos que creen y comparten este sueño, el cual hoy crece con su segundo número, expandiéndose desde nuestra Región hacia el mundo, mostrando que somos plurales y que estamos contribuyendo con el crecimiento del conocimiento global.

Jaime De La Ossa Velásquez, Dr.

Editor 